\title{
Work-Life Balance among Academic Staff of the University of Lagos
}

\author{
Ayotunde Adebayo ${ }^{1}$ \\ ${ }^{1}$ Department of Arts and Social Sciences Education, University of Lagos
}

\begin{abstract}
Work-life balance is associated with the maintenance of stability in both one's professional and personal life. It is key to the welfare and, subsequently, job satisfaction and productivity of employees. It is against this understanding that this study surveyed the way academic staff of the University of Lagos perceive and pursue work-life balance at the University. The findings were that the academic staffs understand work-life balance and its importance. However, the University has no policy on the same and the respondents reported a poor work-life balance that is tilted towards work roles. The implications of these findings are discussed after which recommendations for improvement are propounded.
\end{abstract}

Keywords: HRM, Job Satisfaction, Work-life Balance.

\section{$1 \quad$ Introduction}

A commentator has opined that 73 percent of teachers reported that they often find their work quite stressful. Consequently, they are more likely to leave their work emotionally and physically exhausted and, often, they take work home. Any teacher that fails to strike a balance between work and private life risks becoming burned out (http://education.cu-portland.edu/blog/educator-tips/fivetips-for-teacher-work-life-balance/). In the modern business environment, people interact with each other from different locations at different times. Employers can communicate with their staff at any time so they can obtain staff services as they require. Likewise, staff interact with their personal relations during working hours. Work-life balance demands having time for oneself on a daily basis whilst it is ensured that this does not affect one's performance in the workplace. 
Organisations are beginning to understand the importance of work-life balance and as such resources are being expended in a bid to encourage staff to balance work and non-work roles so as to enhance productivity. Also, in an attempt to increase the level of job quality and reduce the incidence of error in the workplace, organisations need to ensure that their staffs have a level of balance between work and social life that is deemed to be satisfactory.

There are several stress building factors that influence the performance of staff in universities. And it is with this cognizance that this study focuses on ways of improving the work-life balance and, subsequently, job satisfaction of academic staff of the University of Lagos. This was based on the understanding that, currently, academic staffs of the University of Lagos are stressed on the job, a problem that could affect their job satisfaction.

\section{$2 \quad$ Related Literature}

According to Lockwood (2003) there are three main factors influencing worklife balance in organisations. These are: increase in competition in the global business environment; growing interest in family values; and the emergence of an aging workforce. This study uses the work-life balance framework developed by the New Zealand government in 2014. This framework focuses on three distinctive areas: 1) assessment of work-life balance and its needs; 2) effective evaluation of work-life balance; and 3) review of work-life balance and implementing it as a strategic approach to achieving success. In a bid to improve staff job satisfaction at the University of Lagos, this study aims to focus on an effective framework that helps support and drive the development of programmes that will encourage the maintenance of stability in the lives of staff.

Life in itself is a balancing act and it is logical to imply that most people are seeking ways to balance their work-life. Work-life balance has several attributes. This has made it difficult to coin a definition for this concept and as such various experts and scholars have different views and perception of the things that constitute it. In this study, there are terms used in work-life balance that would be described in various ways as defined by various experts (Lockwood, 2003; Reddy, 2012; Kumari, 2012):

1. Work-family Conflict: This is regarded as the push and pull effect experienced between work and family responsibilities.

2. Work-Life Balance: From an employee's perspective, work-life balance is the act of managing work responsibilities and personal obligations. However, from an organisation's perspective, it is the act of establishing a business cultured environment that is supportive towards staff focusing on their jobs. 
3. Work-Life Programs: This is a term used when an organisation offers their staffs the opportunities of addressing work related and personal issues.

4. Work-Life Culture: This is a scenario where the culture of an organisation respects its staffs' family responsibilities and also encourages the staffs to attend to both these responsibilities and the demands of their work.

5. Work-Life Initiative: This involves an organisation creating policies that guide the behaviour of staff with the view of getting the jobs done whilst giving them opportunities to address their personal issues.

One of the objectives of human resources departments is to ensure balance between the work and personal life of staff. In an attempt to combine both personal and work-life, both positive and negative impacts arise. Staffs do not offer their full concentrations at work, thereby, reducing their performance on the job due to personal reasons. Likewise, in their personal life, staffs are anxious about their job roles and responsibilities and as a result they cannot excel in their work-life (Lockwood, 2003). Therefore, it is important to maintain a satisfactory balance between work and personal life.

For the purpose of this study, work-life balance can be described as the balance between work-life and personal life. Reddy (2012) suggests that worklife balance is described as the relationship attained between work that an individual is being paid for and the lives individuals live outside of their paid employment. A state of equilibrium can be reached between these two phases based on the needs and expectations of the individual. The intensity and stress of an individual's job can affect one's work-life balance. According to Yayday (2013), work-life balance can help increase the satisfaction got from carrying out job duties. As the number of working hours increase, the work-life balance is affected.

The performances of organisations are particularly influenced by the worklife balance of staff. This is owing to the fact that staffs face challenges and stress related issues that affect their performance on the job, thereby negatively influencing the overall performance of the company. According to Lubna (2013), the association of staff with their families during working hours affects the performance of staff on their job roles and responsibilities. Lubna insinuates that singular communication between staff and their families during working hours can cause stress on individual staff, which affects the quality of job done on a daily basis. It can also reduce the level of concentration of the staff thereby affecting the level of efficiency on the job. This hints that there is a link between work-life balance and the motivation of staff in an organisation. It is important for an organisation to help staff to strike a suitable and satisfactory balance between their work and personal life so as to achieve a satisfactory level of performance at work. 
In scenarios where staff are asked to work longer hours, the issue of worklife balance arises even more than before (Ojo, Falola \& Mordi, 2014). Therefore, organisations are increasing the benefits and perks to staff so as to increase their motivation to work and achieve sterling performance. The Nigerian university sector is one that involves staff working extra hours (Ojo et.al, 2014a). Staff who decide to work longer hours are usually seen as diligent and competent in their duties irrespective of whether significant value is added during this period of extra work. Due to this, staff work longer hours in the Nigerian university sector because of incentives offered and the basic consideration for promotion during performance appraisal (Yaday, 2013). It is worth mentioning that the effectiveness of staffs' performance could reduce due to increase in working hours.

According to Lockwood (2003), an individual should be reasonable enough to work for reasonable hours so as to equally balance one's work-life. However, workaholics work for extra odd hours which are regarded as a work-life that is not balanced due to the fact that individuals do not realise the standards and rules regarding how much time and energy should be dissipated on professional work. This results into a struggle between work-life and personal life.

In order to achieve work-life balance, an individual needs to consider the time spent on their work and non-work roles (SSC, 2014). For an individual whose social needs are extremely demanding, working extra odd hours might be detrimental to their social life. However, an individual who does not have a demanding social life but works extra hours might not experience serious challenges in this regard. In recent times, staff of organisations are working extra hours so as to fulfil the requirements of the company they work for and in return the organisation rewards them with monetary incentives (SSC, 2014). These extra-long work hours have benefited staff through the benefits and bonuses given by the organisation to the staff. These bonuses have helped the staff to meet their needs at the time it is needed the most. However, Reddy (2012) argues that on the other hand, these scenarios have negatively affected the family lives of staff. The extra-long working hours have caused a lot of imbalance in the work and social life of the employees. Therefore, it follows some logical assumptions that the family life of staff have been affected as a result of the blend and merger of the professional and personal life.

Lubna (2013) also notes that some staff work during holidays and their offwork hours. Despite the fact that these staff are being rewarded for these in which case it helps the staff financially, it is worth mentioning that there is no replacement of the satisfaction gained when one spends quality time with family or loved ones.

Prior to technological advancement in the global business environment today, life was not as fast paced and connected with every personal and business update. Today, technology has evolved and created various means of 
communication and as such interaction with one another has become easy. According to Kumari (2012), technological devices have helped individuals stay in contact with each other for the entire day. Viewing this from the perspective of overcoming communication barriers definitely proves to be useful. However, this has made individuals deal with so many issues simultaneously through which the maintenance of balance between the different things in their work and personal lives is difficult.

Organisations require staff to provide quality service to their customers, resolve customer complaints and offer innovative solutions to customers' needs. Likewise family members demand to remain in constant communication with the individuals performing the job duties of organisations with the aim of seeking solutions to their problems at the time of need (SSC, 2014). Viewing both scenarios, each perspective is significant in its own right and it is right to say that they overlap each other. At times, an individual's work-life might rule over the personal life, which can be detrimental to the social life of the individual. Likewise, if the social life of the individual encroaches into the work-life, it could affect the performance of the individual, which could become an issue at the individual's workplace. In a nut shell, both the social and work-life should be balanced so as to achieve success in both areas of life (Lockwood, 2013).

Organisations have corporate goals which are to be achieved by staff through the delivery of quality and efficient service. Still, when organisations do not achieve their desired results, staff might be required to work extra time. On the other hand, staff are constantly in touch with their families and loved ones during working hours in which their attention span is reduced and diverted to different things when carrying out job duties. This can cause major problems for the organisation.

Kumari (2012) suggests that an effective synergy between an individual's personal and work-life can yield positive results on performance. Likewise, if a staff receives bad news from his or her social life, it can negatively affect his/ her performance by creating stress and unnecessary tension in the workplace. Therefore, it is important that a satisfactory balance is struck between an individual's work and social life so as to achieve overall satisfaction on the job and non-work roles.

Institutions are beginning to realise that it is not right to dedicate all one's life to an organisation whilst neglecting his or her personal life (Ojo, Salau and Falola, 2014b). Therefore, organisations help staff strike a balance between work and social life thereby improving and developing the employee's relations at the workplace. This is logical because an employee who is stable socially has the potential to be stable at the workplace. Also, staff would be more motivated to work and fully utilize their skills and capabilities in a bid to add value to the organisation (Yaday, 2013). 


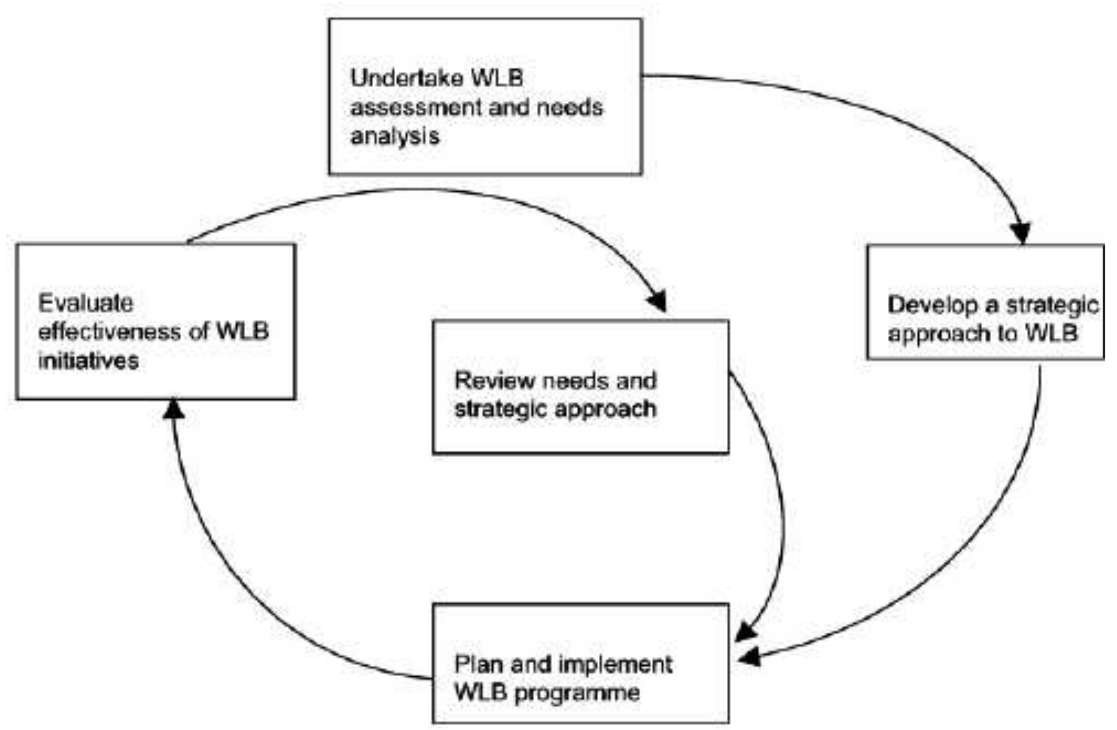

Figure 1 Work-Life Balance Framework

Source: SSC (2014)

Figure 1 shows the strategic approach to work-life balance in an organisation. The framework depicted in Figure 1 focuses on three distinctive areas:

1. The assessment of work-life balance and its needs in an organisation

2. The effective evaluation of work-life balance

3. The review of work-life balance and implementing it as a strategic approach to achieving success.

In the quest to developing healthy sound innovative minds for staff, organisations are beginning to offer various facilities to staff such as vacations, benefits and rewards so as to ensure a healthy and significant time is being spent with their families - in which case would eventually be beneficial to the overall performance of the company (Lockwood, 2013).

\section{$3 \quad$ Methodology}

The study followed a case study design. Data were collected using interviews. A random sample of 26 respondents were selected to participate in the research process. These included associate professors (7), professors (3) while the other sixteen (16) included senior lecturers, lecturers, assistant lecturers and assistant 
lecturers. During the interview process, the researcher seized the opportunity to ask questions regarding the nature of the work-life balance of the academic staff and how it affects the satisfaction each individual derives from their job. All the interview questions asked were structured prior to the interview process. The interview focused on four areas related to work-life balance: 1) General issues on Work-life; 2) Work-life balance; 3) challenges; and 4) Policies. The interview questions were structured along these thematic areas so as to enable the researcher to focus on issues that surround the work-life balance of the respondents. The validity of the research instrument implemented in this research was scrutinized by the experts on human resources management. The reliability of research instrument was achieved through test retest method using Person Product Moment Correlation statistic. This returned a correlation coefficient of 0.72 meaning that the instrument was reliable. The data were analysed using content analysis, through which themes were systematically identified from the responses elicited from the respondents.

\section{$4 \quad$ Findings}

\subsection{Knowledge of and Policies on Work-Life Balance}

Five (5) lecturers stated that work-life balance is the balance between one's life at work and the time spent on social activities. Fifteen (15) lecturers stated that the achievement of work-life balance in the university system is difficult due to the number of working hours expended on the job. However, for definition purposes, they all acknowledged that work-life balance is the balance between work and personal life.

All twenty six (26) lecturers interviewed stated that they are not aware of any work-life balance policy presently in place to help lecturers with their work and personal life. The only notable policy is the encouragement given to lecturers to always go an annual leave as long as there are colleagues to assist to teach their courses when they are away on leave.

\subsection{Hours Spent at Work}

Eleven (11) lecturers stated that they work an average of twelve (12) hours a day due to their basic job functions. Three (3) lecturers interviewed stated that they resume work at $7.30 \mathrm{am}$ and close at $9.00 \mathrm{pm}$ which is an average of 13.5 hours worked. All lecturers interviewed seemed not to be happy about the working hours currently expended on jobs on a daily basis. It was stated by five (5) lecturers that they live very far from their workplaces and are usually tired 
when they get to work in the morning. They further stated that they get an average of five (5) hours sleep every day and they tend not to be quite productive at work the next day.

\subsection{Attitude towards Job and Incidence of Work-Related Pressure}

Thirteen (13) lecturers interviewed stated that they liked their jobs. However, they further stated that they are willing to learn new things by doing other jobs outside of what they presently do. Seven (7) stated that they do not like their jobs because they are bored and tired of repetitions. They further stated that their level of productivity is low and they tend to avoid committing blunders on the job. Three (3) lecturers stated that they were indifferent as to whether they like the job or not.

All twenty six (26) lecturers stated that they face work pressures every day at work. Seventeen (17) lecturers interviewed who happened to be cohort advisers stated that they face pressures every day in addressing students' problem on examination results and broad mark sheets. They seemed to complain about unrealistic targets set by the University which increases the pressure to perform. It was also stated that this pressure affects their lives outside work.

\subsection{Work Motivation}

Ten (10) lecturers stated that they are not currently motivated on their jobs. It was gathered that they have not been promoted as at when due. They stated that this has affected their performance as they do not fully commit themselves to the job anymore. Six (6) lecturers stated that they were motivated to do more because they are promoted as at when due. However, they stated that they find themselves working longer hours than their contemporaries in other universities.

\subsection{Holidays and Sick Leave}

All twenty six (26) lecturers interviewed stated that they are all entitled to forty two (42) working days of annual leave. However, it was stated by nineteen (19) lecturers that it is sometimes difficult to go on leave because most Head of Departments are reluctant to approving lecturers leave due to overwhelming requirements on the job. It was gathered from all lecturers that the university grants sick leave to lecturers as the case may require. 


\subsection{Opportunities for Promotion}

Ten (10) lecturers interviewed lamented that they have not been promoted as at when due. They further suggested that this is affecting their performance on the job and their level of motivation has reduced. All other lecturers interviewed stated that most lecturers are promoted in a space of 3 to 4 years. It was further revealed that these promotions are not usually objective in nature.

\subsection{Rotation of Job Functions and Supervisory Support}

Twenty (20) lecturers interviewed stated that they are tired of doing the same job every day. They stated that they would be excited to perform other job roles within the university. Other lecturers interviewed stated that they have been rotated to teach other courses within their departments during the course of their job in the university.

Twenty one (21) lecturers interviewed stated that their bosses are not usually appreciative of their performance on the job. They further stated that this in itself has reduced their morale and has made them feel less of themselves. It was also gathered that they constantly experience pressures at work. Five lecturers (5) interviewed stated that their bosses sometimes appreciated them. However, it would be better if the line managers did that more often.

\subsection{Quality Time Spent on Social Activities}

Twenty (22) lecturers stated that they do not spend quality time on social activities. It was stated that they spend most of their time at work, It was further gathered that they sometimes come to work during weekends for marking and grading assignments and sometime to prepare instructional materials in which no incentives or extra pay are given towards this.

All twenty six (26) lecturers interviewed stated that they seldom spend time with their families. It was further gathered that the only have weekends to spend quality time with their families. However, it was stated that they are sometimes required to come to work during weekends which encroaches into their personal life.

A total of twenty one (21) lecturers interviewed stated that they work an extra of four hours outside their normal working hours. It was also gathered that they are not paid for the extra hours dissipated on the job. It was further stated that most times, the extra hours expended on the job are not always seen to produce any value to the organisation because the lecturers are seen to be less productive at the time. Five (5) lecturers stated that they work an average of two extra hours. They also corroborated the view that no extra pay is given for extra hours spent on the job. 


\section{Discussion, Conclusions and Recommendations}

Baral (2010) has argued that employees output are often diminished when they are bored by doing routine jobs. It was found that most lecturers are tired of performing the same job functions. This could result into reduced quality of service and increased error rate. University of Lagos should introduce a course rotation policy within the various areas of competency so as to enable lecturers to be more up-to-date in their jobs. This is supported by Joshi (2007). Lecturers would not be bored on new course roles as they would be more motivated to learn new things. This may enhance job satisfaction.

It was seen that the university sets unrealistic targets for the lecturers hence pressurising the respondents. Therefore, it is imperative that the University sets realistic targets. As Bailyn, Drago and Kochan (2001) argued, if the pressure of employees is not effectively managed at work, it would affect their family life outside work. This in-turn would be detrimental to their performance on the job at University of Lagos. Therefore it is important that the university helps their lecturers strike a balance between their work and life outside work.

Banerjee (2007) opined that organisations should endeavour to reward and promote their staffs when due. This is apposite in the University so as to ensure performance and increase in motivation. This also helps in achieving satisfaction on the job. The "publish or perish" maxim can be reviewed because many lecturers devote more time to publishing papers and less time to teaching. Conversely, many lecturers that devote more time to teaching almost have little time left for publishing. Either way, this creates stress on the lecturers.

Barnett and Hyde (2001) support the need for employees to take vacations. They argued that it is bad manpower planning that makes it difficult to find replacement for anybody on a job function. In the present study, it was seen that most heads of departments are often reluctant to approving lecturers' annual leave. The administration department of the university should enforce the right to annual leave (cf. Beatty, 1996). The management of the University should also encourage head of departments to allow their lecturers go on leave when due so as to reduce the pressure and tension the lecturers face at work. The usage of annual leave by lecturers makes them relax with their families and reduce the work pressure built in them. They eventually return to work refreshed and ready to fully utilize their skills (Beauregard, 2006).

Heads of departments should learn to appreciate their subordinates. This will help in boosting their morale, motivation and performance. In this regard, the findings of the present study are at variance with those of Bellavia and Frone (2005) who observe that feelings of being appreciated at work enhances job satisfaction and motivation.

The university should encourage lecturers to have time for social activities and also encourage them to stabilise their work-life with their social life so as to 
improve on their performance (Bhargava and Baral, 2009). Buddhapriya (2009) opines that leisure time with family members is a crucial obligation that must be built into work life. This supports the view that lecturers of the university should reduce the extra hours spent on the job so as to create time for personal life. During the day, lecturers reach a point whereby they tend not be productive anymore. This leads to reduction in job satisfaction. We have seen instances when lecturers collapsed in their offices and there is need to forestall this possibility from happening again the future.

A work-life balance policy should be developed to guide lecturers on how to strike a satisfactory balance between the time they spend at work and the time they spend on non-work roles. Butler et al. (2005) have argued for a work-life balance policy that will be enforceable throughout the organisation. This would help to enhance the quality of service delivery at the University.

The implementation of an ideal work-life balance programme would be extremely useful to the enhancement of job satisfaction in University of Lagos. The results got from the interviews showed that University of Lagos lecturers are presently not achieving job satisfaction and this is affecting the quality of their teaching and research. The benefits of this programme will accrue to the lecturers, students and the University (employer) and they will include increased productivity; higher job satisfaction, commitment and retention; improved quality of teaching and research; and reduced costs due to redundancy and health issues.

\section{References}

Bailyn, L., Drago, R., Kochan, T. A. (2001). Integrating work and family life: A holistic approach. A Report of the Sloan Work -Family Policy Network. Boston M. A.: MIT Sloan School of Management.

Banerjee, I. (2007). Harnessing work-life balance: A shared responsibility. HRM Review, December, 26-31.

Baral, R. (2010). Work-family enrichment: Benefits of combining work and family. Retrieved October 7, 2010, from: http://www.paycheck.in/main/work-andpay/women-paycheck/articles/workfamily-enrichment-benefits-of-combiningwork-and-family.

Barnett, R. C., Hyde, J. S. (2001). Women, men, work, and family. An expansionist theory. American Psychologist, 56, 781-796.

Beatty, C.A. (1996). The stress of managerial and professional women: Is the price too high? Journal of Organizational Behaviour, 17, 233-251. 
Beauregard, T. A. (2006). Are organizations shooting themselves in the foot? Workplace contributors to family-to-work conflict. Equal Opportunities International. 25 (5), 336-353.

Bellavia, G. M., Frone, M. R. (2005). Work-family conflict. In J. Barling, E. K. Kelloway \& M. R. Frone (Eds.), Handbook of Work Stress, pp. 113-147. CA: Sage.

Bhargava, S., Baral, R. (2009). Antecedents and consequences of work-family enrichment among Indian managers. Psychological Studies, 54, 213-225.

Buddhapriya, S. (2009). Work-family challenges and their impact on career decisions: A study of Indian women professionals. Vikalpa, 34 (1), 31-45.

Butler, A. B., Grzywacz, J. G., Bass, B. L., Linney, K. D. (2005). Extending the demands control model: a daily diary study of job characteristics, work family conflict and work-family facilitation. Journal of Occupational and Organizational Psychology, 78, 155-169.

Joshi, R. (2007).Work-life balance: Making it work for you(r) business. HRM Review. December, pp. 20-24.

Kumari, L. (2012). Employees' perception of work-life balance and its relation with job satisfaction in Indian public sector banks. IJEMR, 2 (2), 1-13.

Lockwood, N. R. (2003). Work-life Balance: Challenges and Solutions. Research Quarterly. Pp. 1-10

Lubna, R.V. (2013). An Empirical Study on the Effectiveness of Work-Life Balance in the Banking Industry. Life Science Journal. 10 (4), 3075-3081.

Ojo, I. S., Falola, H. O., Mordi, C. (2014a). Work-life Balance Policies and Practices: A Case Study of Nigerian Female University Students. European Journal of Business and Management. 6 (12), 184-193.

Ojo, I.S. Salau, O. P., Falola, H. O. (2014b). Work-life Balance Practices in Nigeria: A Comparison of Three Sectors. Journal of Competitiveness. 6 (2), 3-14.

Reddy, M. L. (2012). Empirical Evidence on Work-life Balance in the Banking Sector. Asian Academic Research. Journal of Social Science and Humanities. 1 (6), 1-7.

SSC (2014). Work Life Balance: A Resource for the State Services. [Online] (http://www.ssc.govt.nz/node/6868. Accessed 12/9/16). New Zealand Government. New Zealand

Yaday, R (2013). Work-life Balance Challenges for HRM in the Future. International Journal of Current Research. International Journal of Current Research, (5) 10, 2966-2969. 